\title{
Possibilities and limitations of LCA for the evaluation of soil remediation and cleanup
}

\author{
V. Cappuyns \\ Hogeschool-Universiteit Brussel, Centre for Economics and Corporate \\ Sustainability (CEDON), Belgium
}

\begin{abstract}
When evaluating remediation technologies for contaminated soil and groundwater, the beneficial effect of the remediation, namely cleaner soil and groundwater, are mostly emphasized without consideration of the environmental impact of the remediation activities themselves. Nevertheless, practitioners and decision makers can rely on a broad range of decision tools that can help them to achieve a better balance between economic, social and environmental health aspects of contaminated land remediation. A holistic approach for the management of contaminated land should ideally include an assessment of the environmental risk of the contamination, an assessment of the environmental, social and health impact of the remediation process and a cost-benefit analysis of the remediation project.

A life cycle framework, including a life cycle management (LCM) approach structuring environmental activities and life cycle analysis (LCA) for a quantitative examination, can be helpful for the selection of site remediation options with minimum impact on the ecosystem and human health. During the last 10 years, several instances have emerged in which a life cycle approach has been applied to the remediation of contaminated sites. Besides addressing the environmental impact of the remediation activities for a specific site, attention should also be paid to the consequence of reintroducing a remediate site into the economy. From a legal point of view, there should be ways to encourage the use of sustainable remediation technologies, together with a disconnection of treated soils from the definition of waste. Finally, the focus should move from remediation, whether sustainable or not, to the prevention of soil contamination.. Keywords: environmental risk, heavy metals, impact assessment, life cycle management, soil contamination, sustainability.
\end{abstract}




\section{Introduction}

\subsection{Policy on soil remediation in Europe}

Approximately 250,000 sites in Europe require cleanup, while the European Environmental Agency estimates that nearly 3 million sites are potentially polluted [1]. Industrial activities are responsible for over $60 \%$ of Europe's soil pollution (the oil sector accounts for $14 \%$ of this total). Among the most common harmful contaminants are heavy metals (37\%) and mineral oils (33\%) [1]. Although several EU directives support the prevention and cleanup of soil contamination (e.g. EU Directive on Environmental Liability, EU Waste Framework Directive, EU Water Framework Directive, EU Integrated Pollution Prevention and Control Directive), there is no general European directive with regard to Soil Remediation and cleanup. Because the cleanup of all historicallycontaminated sites to background concentrations or levels suitable for all types of land use is not considered technically or economically feasible, cleanup strategies are more and more designed to use sustainable, long-term solutions, often using a risk-based approach to land management.

In some countries the selection of soil remediation options is based on the best available technology (BAT). Some other countries, including Flanders (Belgium), take the best available technology not exceeding excessive cost (BATNEEC) as a criterion for selecting soil remediation options. Despite the fact that BAT is likely to represent the most technologically feasible tool for soil remediation, BATNEEC seems a more suitable framework for decisions regarding soil remediation projects.

Sorvari et al. [2] point to the fact that existing policy instruments do not promote sufficiently eco-efficient site remediation technologies. Besides the development of a more eco-efficient policy for contaminated site management, there is a need to promote the use of more eco-efficient site remediation techniques. An important aspect of this is the development of methods that allow assessment of the eco-efficiency of site remediation options. Additionally, the knowledge of decision support tools that take into account eco-efficient or even sustainable remediation options, among stakeholders that have to decide on which site remediation options to pursue, should be improved.

\subsection{Selection of remediation techniques for contaminated land}

As stated above, the decision process for selecting the technique for remediation of contaminated sites has traditionally focused on the cleanup level, the time required for the remediation, economic resources and the best available technologies. Other factors that are relevant for the remediation of contaminated sites include the sustainability of the remediation process and the view of the stakeholders on the remediation solution [3]. Sustainability of the remediation of contaminated land takes into account 3 main aspects: (1) economic aspects (e.g. cost of remediation); (2) ecological aspects (e.g. environmental aspects of remediation such as emissions to surface waters) and (3) social aspects 
(e.g. communication to stakeholders). Although soil remediation is often considered to be a completely positive process because of the reduction or removal of soil contamination, the overall consequences and impact of the soil remediation process should also be considered. Under the European Commission's Framework Programme 5, the Concerted Action CLARINET brought experts and regulators from 16 European countries together to identify means by which contaminated land could be managed in an effective but sustainable manner. As a follow-up action to implement the recommendations of this Concerted Action, the SNOWMAN project is to analyze the possibilities for improving co-operation in Europe between national research programs in the field of soil and groundwater management where there is the presence of contamination [4]. The European Coordination Action for Demonstration of Efficient Soil and Groundwater Remediation (EURODEMO) promotes sustainable, cost-effective soil and groundwater remediation technologies. This leaves us with the fundamental question: what constitutes sustainable remediation of contaminated soil?

Harbottle et al. [5] defined 5 criteria that have to be met in order to classify a remediation project as 'sustainable'(Table 1).

Table 1: $\quad$ Five criteria for a sustainable remediation project (after [5]).

\begin{tabular}{|c|c|c|}
\hline 1 & Criterion & Comment \\
\hline 2 & $\begin{array}{c}\text { Future benefits outweigh cost of } \\
\text { remediation } \\
\text { Overall environmental impact of } \\
\text { the remediation process is less } \\
\text { than leaving the land untreated }\end{array}$ & $\begin{array}{c}\text { Besides the economic cost, societal } \\
\text { benefits also have to be taken into } \\
\text { account. }\end{array}$ \\
\hline 3 & $\begin{array}{c}\text { Environmental impact due to the } \\
\text { application of the remediation } \\
\text { process is minimal and measurable } \\
\text { you take into account and which not? }\end{array}$ & $\begin{array}{c}\text { Boundaries of the impact assessment } \\
\text { have to be defined. There should be } \\
\text { a consensus on the way to express } \\
\text { 'environmental impact' in an } \\
\text { objective way. }\end{array}$ \\
\hline 4 & $\begin{array}{c}\text { The time-scale over which the } \\
\text { environmental consequences occur } \\
\text { (including intergenerational risk) } \\
\text { is part of the decision making } \\
\text { process. }\end{array}$ & $\begin{array}{c}\text { The soil should be restored in a } \\
\text { sustainable manner so that both } \\
\text { current and future generations can } \\
\text { satisfy their ecological, economic } \\
\text { and social needs }\end{array}$ \\
\hline 5 & $\begin{array}{c}\text { The decision-making process } \\
\text { includes an appropriate level of } \\
\text { engagement of all stakeholders }\end{array}$ & $\begin{array}{c}\text { What can the role of different } \\
\text { stakeholders be in every aspect of } \\
\text { the decision making process }\end{array}$ \\
\hline
\end{tabular}

Sustainable soil remediation can also be addressed from the point of view of the sustainable use of resources. Both soil and groundwater can be considered valuable resources. Ideally, remediation and/or cleaning of soil and groundwater should be performed in a closed-loop system, with conservation of landscape 
characteristics, to minimize the environmental impact of the remediation project and to achieve the goal of 'sustainable use of soil'.

The term "green or gentle remediation techniques" is closely related to "sustainable remediation, as "green remediation techniques" are defined as remediation techniques with a lower environmental impact and a lower associated consumption of natural resources such as water and energy [6]. Nevertheless, only one aspect of "sustainability", namely, the environmental aspect, is taken into account.

In the present paper, attention is first paid to the assessment of the environmental impact of the soil remediation process and on the way this environmental impact is quantified by means of life cycle assessment (LCA) methodology. On the one hand, some possibilities of using LCA for the evaluation of soil remediation are illustrated with examples from literature. On the other hand, some additional aspects that should be accounted for in the sustainable remediation of contaminated land and that are not or only partly addressed in LCA, are discussed.

\section{Evaluation of the environmental impact of soil remediation by LCA}

The environmental impact of soil remediation is one of the aspects that deserve more attention during soil remediation. Since the 1990's, several tools have been developed to assess the environmental impact of processes and products, such as eco-indicators and other tools based on Life Cycle Assessment (LCA). Since the last decade, LCA has been gaining wider acceptance as a tool for the quantification of environmental impacts and evaluation of improvement options throughout the life cycle of a process, product or activity [7]. A Life Cycle Analysis is carried out in four distinct phases: (1) definition of goal and scope, (2) Life cycle inventory, (3) life cycle impact assessment and (4) interpretation [8]. Historically, LCA has mainly been applied to products, but several examples (e.g. [9]) show that it can assist in identifying more sustainable options in process selection design and optimization.

A life cycle framework, including a life cycle management (LCM) approach structuring environmental activities and life cycle analysis (LCA) for a quantitative examination, can be helpful for the selection of site remediation options with minimum impact on the ecosystem and human health [10].

\subsection{Application of LCA to the remediation of contaminated sites}

During the last 10 years, several instances have emerged in which a life cycle approach has been applied to the remediation of contaminated sites.

In a literature review, Suér et al. [11] illustrate that the result of LCA is highly dependent on the method used and that the choice of impact categories heavily affects the outcome of an LCA study. An updated overview (Table 2) of case studies dealing with LCA of the remediation of contaminated sites illustrates the high variation in impact assessment methods that have been used over the last 
Table 2: Literature overview of LCA-based case studies where the impact of soil remediation technologies were evaluated.

\begin{tabular}{|c|c|c|}
\hline Ref & Case study & $\begin{array}{c}\text { Impact assessment method or } \\
\text { tool }\end{array}$ \\
\hline [19] & - & $\begin{array}{l}\text { REC (uses value functions method } \\
\text { for assessment of environmental } \\
\text { merit) }\end{array}$ \\
\hline [20] & - & $\begin{array}{l}\text { Calculation of potential impact } \\
\text { indicators }\end{array}$ \\
\hline [10] & & $\begin{array}{c}\text { Multimedia Maclkay model } \\
\text { Solid Waste Burden (SWB) }+ \\
\text { useable land area }\end{array}$ \\
\hline [17] & $\begin{array}{c}\text { Site contaminated with mineral oil, } \\
\text { PAH and Cr }\end{array}$ & Use of 'disadvantage factors \\
\hline [21] & - & $\begin{array}{l}\text { pollution factor (PF) is calculated, } \\
\text { and expression of environmental } \\
\text { impacts in dimensionless } \\
\text { environmental impact units (EIUs }\end{array}$ \\
\hline [18] & $\begin{array}{l}\text { Industrial site contaminated with } \\
\text { sulfur }\end{array}$ & $\begin{array}{c}\text { No impact assessment but ranking } \\
\text { of productivity resources }\end{array}$ \\
\hline [22] & $\begin{array}{l}\text { spent pot lining (SPL) landfill } \\
\text { contaminated with } \mathrm{Cd} \text { and } \mathrm{Cu}\end{array}$ & $\begin{array}{c}\text { EDIP97 + simulation of } \\
\text { contaminant transport in } \\
\text { groundwater, using site-specific } \\
\text { data }\end{array}$ \\
\hline [12] & Diesel-contaminated site & EDIP97 \\
\hline [23] & Old landfill & $\begin{array}{c}\text { Specific method for impact } \\
\text { assessment transport of heavy } \\
\text { metals }\end{array}$ \\
\hline [24] & former manufactured gas plant site & $\begin{array}{c}\text { Characterisation method adopted } \\
\text { from UBA }(2000),\end{array}$ \\
\hline$[5]$ & $\begin{array}{c}\text { Mixed industrial-residential- } \\
\text { commercial area with BTEX and } \\
\text { THP contamination }\end{array}$ & IPPC Tier Two methodology \\
\hline [25] & $\begin{array}{l}\text { Brownfield contaminated by } \\
\text { human activity in railway sector }\end{array}$ & IMPACT2002+ \\
\hline [14] & Diesel-contaminated site & US-EPA TRACI \\
\hline [26] & $\begin{array}{c}\text { Industrial site with } 300 \text { industries } \\
\text { involved in chemical and } \\
\text { petro-chemical productions }\end{array}$ & $\begin{array}{l}\text { DEcision Support sYstem for } \\
\text { REhabilitation of contaminated } \\
\text { sites (DESYRE). }\end{array}$ \\
\hline [16] & Previous oil depot & $\begin{array}{c}\text { ReCiPe } \\
\text { EPD }\end{array}$ \\
\hline [15] & $\begin{array}{l}\text { Industrial site with distribution } \\
\text { centre for new cars }\end{array}$ & REC \\
\hline
\end{tabular}

10 years. Besides primary impacts, associated with the state of the site and secondary impacts, associated with the site remediation itself [12], LCA for contaminated site management should also account for tertiary impacts, associated with the effects of the reoccupation of the site [13]. Therefore, 
different scenarios could be considered and the collection of additional data concerning temporal and spatial effects should be integrated into the evaluation of contaminated sites [11]. For example, Cadotte et al. [14] considered two different remediation scenarios: one based on a fast treatment time and another one based on a low environmental impact.

Cappuyns et al. [15] compared two remediation scenarios for a site with a LNAPL contamination by applying the BATNEEC (Best available technique not entailing excessive costs) method and the LCA-based REC (Risk Reduction, Environmental Merit and Costs) method. They concluded that, although an LCA-based evaluation method is much more complex and requires much more data than a classical BATNEEC analysis, both evaluation tools could be used in a complementary way. A preliminary selection of remediation technologies could be based on a BATNEEC analysis, followed by a detailed analysis of the selected remediation options by means of LCA. When alternatives for soil remediation are compared, one should be aware that environmental effects occur on very different environmental problems and geographical scales [16], pointing to the importance of including land use in LCA.

It also clear from Table 2 that most case studies deal with sites contaminated with organic contaminants. Sites contaminated with heavy metals $[17,22]$ or sulfur [18] are only the subject of a few case studies.

\section{Other aspects not or only partly addressed in LCA}

Practitioners and decision makers can rely on a broad range of decision tools that can help them to achieve a better balance between economic, social and environmental health aspects of contaminated land remediation [27]. A holistic approach for the management of contaminated land should ideally include an assessment of the environmental risk of the contamination, an assessment of the environmental, social and health impact of the remediation process and a costbenefit analysis of the remediation project [27].

\subsection{Ecosystem services to define the goal of the remediation project}

The relative sustainability of a soil remediation project also depends on the objectives of the remediation [28], so that it is not possible to give an overall 'sustainability score' to a specific soil remediation technique. More and more, the concept of 'ecosystem services' is taken as a starting point to determine the goal of a soil remediation project. Ecosystem services can be defined as the resources and processes that are supplied by natural ecosystems. Cleanup activities can modify ecosystem services, so the determination of ecosystem services is important to avoid unwanted negative effects of soil remediation operations. Ecosystem health is quantified in LCA by linking inventory systems to so-called impact categories. During the last decade, developments in Life cycle analysis have resulted in the definition of so-called mid-point impact categories, such as ecotoxicity and global warming potential. These indicators are characterized by a relatively low uncertainty and a relatively easy 
interpretation. On the other hand, end point indicators such as biodiversity have to deal with a lot of uncertainty, which should also be accounted for in LCA [29].

\subsection{Aspects with regard to human health risk assessment and ecotoxicity}

Besides the estimation of contaminant emissions (data inventory faze), fate and exposure modeling and the assessment of ecotoxic effects are essential issues. At the moment, there is no consensus regarding soil quality in the EU. A variety of risk assessment tools is used to assess the risk of contaminated soils towards human health and ecosystem health [30].

Initially, the assessment of the global impact on terrestrial ecosystems within life cycle impact assessment was limited to the impact on soil organisms only because terrestrial vertebrates require a complex modeling that requires data on toxicity upon terrestrial vertebrates and the multiple exposure pathway that should be considered [31]. During the last few years, several impact assessment methods for human health and ecotoxicity have been developed. Pizzol et al. [32] give an overview of different impact assessment methods of heavy metals on human health, but conclude that LCA practitioners should chose each model which has the highest consensus with regard to their specific problem. In the US, the USEtox model is recommended for human and eco-toxicity LCIA, although its uncertainties are still large and it has some limitations as it doesn't consider some metals and is not integrated in any complete LCIA method.

For organic contaminants, changes in concentrations over time, such (bio)degradation, volatilization,... are taken into account in risk assessments. For heavy metals, total concentrations in soil are mostly used as an input in risk assessment models. However, heavy metals in contaminated soil are rarely released completely, as only a portion of heavy metals is "bio-available" or "geoavailable" (which means that the metals can be released and become available for biological uptake).

For remediation projects for soils and sediments, this is of course an important consideration, since only a portion of the total metal load in soils or sediments can be considered as 'geo-available' or mobile. In a risk-conservative approach, it is assumed that all the metals contained in a solid matrix (soil, sediment, waste material,....) will be released. When this 'total metal content' is used as an input in LCA analysis, this will most likely result in an overestimation of the risk associated with the heavy metals. Additionally, LCA typically covers an extended period of time (depending on the life cycle of a product or process), so long-term heavy metal emissions have to be assessed. Te assessment of heavy metal release from soils and sediments on the long term is still controversial. Several methods and procedures have been proposed to estimate the long term emissions of heavy metals contained in soils, sediments and waste materials, but there is no consensus on which method performs best [33]. 


\subsection{Financial aspects and financial risks of soil remediation}

In most remediation projects, a cost-benefit analysis is already carried out. However, the benefits for the environment and human health are well quantified in LCA, but not always expressed in monetary terms and thus not systematically included in the cost-benefit analysis.

Moreover, certain soil remediation technologies, especially the more 'gentle' remediation technologies are characterized with a lot of uncertainty with regard to the time frame in which the final remediation goals will be achieved. Unexpected situations can result in an increase of the costs of the remediation project. This uncertainty associated with soil remediation projects makes it difficult to make a good estimation of the cost of the remediation. Contaminated sites carry great financial risk, and potentially a great liability for their owners and investors toward authorities. Therefore, there is a need for practical tools that help practitioners in choosing the correct technology that will not only be effective but also will minimize the financial risk associated with the cleanup.

\subsection{Involvement of stakeholders}

In the past, remediation techniques have mostly been selected without consulting the many stakeholders that are involved in soil remediation techniques such as, for example, local communities affected by the contaminated land and its related remediation operations. "Interactions among all disciplines and stakeholder groups are essential to forge partnerships that will solve environmental problems, rather than deal with only one aspect in isolation" [34].

Besides addressing the environmental impact of the remediation activities for a specific site, attention should also be paid to the consequence of reintroducing a remediate site into the economy [25]. Brownfield development and the displacement of economic activities from suburban to urban sites can counteract the phenomenon of urban sprawl.

From a legal point of view, there should be ways to encourage the use of sustainable remediation technologies, together with a disconnection of treated soils from the definition of waste [35].

Finally, the focus should move from remediation, whether sustainable or not, to prevention of soil contamination [36]. Some countries (for example Flanders (Belgium)) have already adapted their environmental legislation, putting greater emphasis on prevention, but a lot is still expected from innovative technological solutions.

\section{References}

[1] EEA 2007. Europe's Environment. The fourth assessment. Chapter 2: Environment and health and the quality of life. EEA, Copenhagen, 2007, $441 \mathrm{pp}$.

[2] Sorvari, J., Antikainen, R., Kosola, M.J., Hokkanen, P., Haavisto, T., Eco-efficiency in contaminated land management in Finland-Barriers and 
development needs. Journal of Environmental Management, 90, pp. 1715-1727, 2009.

[3] Vik, E.A., Bardos, P., Brogan, J., Edwards, D., Gondi, F., Henrysson, T., Jensen, B.K., Jorge, C., Mariotti, C., Nathanail, P., Papssiopi, N., Towards a framework for selecting remediation technologies for contaminated sites. Land Contamination and Reclamation, 9(1), pp. 119127, 2001.

[4] Vermeulen, H.J., van Veen, H.J., van Reijsen, I.E.R., 2006. Working together in research and development for sustainable land management in Europe.07.06.2006. Snowman vision paper, 23 pp., 2006.

[5] Harbottle, M. J., Al-Tabbaa, A., Evans, C. W., Assessing the true technical / environmental impacts of contaminated land remediation - a case study of containment, disposal and no action. Land Contamination and Reclamation. 14 (1), pp. 85-99, 2006.

[6] Onwubuya, K., Cundy, A., Puschenreiter, M., Kumpiene, J., Bone, B., Greaves, J., Teasdale, P., Mench, M., Tlustos, P., Mikhalovsky, S., Waite, S., Friesl-Hanl, W., Marschner, B., Ingo Müller. Developing decision support tools for the selection of "gentle" remediation approaches .Science of The Total Environment, 407(24), pp. 6132-6142, 2009.

[7] Tukker, A., Life cycle assessment as a tool in environmental impact assessment. Environmental Impact Assessment Review, 20(4), pp. 435456, 2000.

[8] Hendrickson, C., Lave, B.L., Matthews, H.S., Environmental Life Cycle Assessment of Goods and Services: An Input-output Approach. Resources for the Future Press (RFF Press), 260 pp., 2006

[9] Klemeš, J., Pierucci, S., Worrell, E., Sustainable processes thorough LCA, process integration and optimal design. Resources Conservation and Recycling, 50(2), pp. 115-121, 2007.

[10] Diamond, M., Page, C., Campbell M., McKenna S. \& Lall R. Life-cycle framework for assessment of site remediation options: method and generic survey. Environmental Toxicology and Chemistry, 18 (4), pp. 788-800, 1999.

[11] Suer, P., Nilsson-Påledal, S., Norrman, J., LCA for site remediation: a literature review. Soil and Sediment Contamination, 13, pp. 415-425, 2004

[12] Toffoletto, L., Deschênes, L, Samson, R., LCA for ex-situ bioremediation of diesel-contaminated soil. International Journal of Life Cycle Assessment, 10(6), pp. 406-416, 2005.

[13] Lesage, P., Ekvall, T., Deschênes, L., Samson, R., Environmental assessment of brownfield rehabilitation using two different life cycle inventory models. Part 2: Case Study. International Journal of Life Cycle Assessment, 12(6), 497-513, 2007.

[14] Cadotte, M., Deschênes, L., Samson, R.., Selection of a remediation scenario for a diesel- contaminated site using LCA. International Journal of Life Cycle Assessment, 12(4), pp. 239-251, 2007. 
[15] Cappuyns, V., Bouckenooghe, D., Van Breuseghem, L., Van Herreweghe, S., Can thermal soil remediation be sustainable? A case study for a site with a L-NAPL contamination. Accepted for publication in Journal of Integrative Environmental Sciences, 2011.

[16] Suer, P., Andersson-Sköld Y., Biofuel or excavation? - Life cycle assessment (LCA) of soil remediation options. Biomass and Bioenergy, 35(2), pp. 969-981, 2011.

[17] Volkwein, S., Hurtig, H.W., Klöppfer, W., Life Cycle Assessment of Contaminated Sites Remediation. International Journal of Life Cycle Assessment, 4(5), pp. 263-274, 1999.

[18] Blanc, A., Métivier-Pignon, H., Gourdon, R., Rousseaux, P., Life cycle assessment as a tool for controlling the development of technical activities: application to the remediation of a site contaminated by sulfur. Advances in Environmental Research, 8(1-3), pp. 613-627, 2004.

[19] Beinat, E., van Drunen, M.A., Janssen, R., Nijboer, M.H., Koolenbrander, J.G.M., Okx, J.P., Schütte, A.R., The REC decision support system for comparing soil remediation options; A methodology based on Risk reduction, Environmental merit and Costs. September 1997, CUR/NOBIS, 93 pp., 1997.

[20] Page, C., Diamond, M., Campbell, M., McKenna, S., Lifecycle framework for the assessment of site remediation options: case study. Environmental Toxicology and Chemistry, 18, pp. 801-810, 1999.

[21] Vignes, R.P., Limited Life Cycle Analysis: A tool for the environmental decision-making toolbox. Strategic Environmental Management, 1(4), pp. 297-332, 1999.

[22] Godin, J., Hainsc, J.F. Deschénesa, L., Samson, R., Combined Use of Life Cycle Assessment and Groundwater Transport Modeling to Support Contaminated Site Management. Human and Ecological Risk Assessment: An International Journal, 10(6), pp.1099-1116, 2004.

[23] Hellweg, S., Hofstetter, T.B., Hungerbuëhler, K., Time-dependent lifecycle assessment of slag landfills with the help of scenario analysis: the example of $\mathrm{Cd}$ and $\mathrm{Cu}$. Environmental Impact Assessment Review, 20(4), pp. 435-456.

[24] Bayer, P. \& Finkel, F., Life cycle assessment of active and passive groundwater remediation technologies. Journal of Contaminant Hydrology 83, pp. 171-199, 2006.

[25] Lesage, P., Ekvall, T., Deschênes L., Samson, R., Environmental assessment of brownfield rehabilitation using two different life cycle inventory models. Part 1: methodological Approach. International Journal of Life Cycle Assessment, 12(6), pp. 391-398, 2007.

[26] Critto, A. \& Agostini, P., Using multiple indices to evaluate scenarios for the remediation of contaminated land: the Porto Marghera (Venice, Italy) contaminated site. Environmental Science and Pollution Research, 16, pp. 649-662, 2009. 
[27] Pollard, S.J.T., Brookes, A., Earl, N., Lowe, J., Kearney, T., Nathanail, C.P., Integrating decision tools for the sustainable management of land contamination. Science of the Total Environment (1-3), pp. 15-28, 2004.

[28] Harbottle, M., Al-Tabbaa, A., Evans, C.W., Sustainability of Land Remediation. Part 1: Overall Analysis, Proceedings of the Institution of Civil Engineers - Geotechnical Engineering, 161 (2), pp. 75-92.

[29] Bare, J.C., Hofstetter, P., Pennington, D.W., de Haes, H.A.U., Life Cycle Impact Assessment Workshop Summary. Midpoints versus Endpoints: The Sacrifices and Benefits. International Journal of Life Cycle Assessment, 5(6), pp. 319 - 326, 2000.

[30] Bone, J., Head, M., Barraclough, D., Archer, M., Scheib, C., Flight, D., Voulvoulis, N., Soil quality assessment under emerging regulatory requirements. Environment International, 36(6), pp. 609-622, 2010.

[31] Haye, S., Slaveykova, V.I., Payet, J., Terrestrial ecotoxicity and effect factors of metals in life cycle assessment (LCA). Chemosphere, 68, pp. 1489-1496, 2007.

[32] Pizzol, M., Christensen, P., Schmidt, J., Thomsen, M., Eco-toxicological impact of "metals" on the aquatic and terrestrial ecosystem: A comparison between eight different methodologies for Life Cycle Impact Assessment (LCIA), Journal of Cleaner Production, In Press, 2011

[33] Pettersen, J., Hertwig, E.G., Critical Review: Life cycle inventory procedures for long-term release of metals. Environmental Science and Technology, 42(13), pp. 4639-4647, 2008.

[34] Burger, J., Environmental management: Integrating ecological evaluation, remediation, restoration, natural resource damage assessment and longterm stewardship on contaminated lands. Science of the Total Environment, 400(1-3), pp. 6-19, 2008.

[35] Wallace, S., Sustainable waste management in contaminated land redevelopment. Land Contamination and Reclamation, 12(2), pp. 101107.

[36] Gilmore I., A critique of soil contamination and remediation: the dimensions of the problem and the implications for sustainable development. Bull Sci Technol Soc. 21: 394-400, 2008. 